\title{
CORPORATE GOVERNANCE, RESEARCH AND ECONOMIC GROWTH IN EUROPEAN COUNTRIES
}

\author{
Iulia (ELENES) PLATONA \\ Department of Marketing and International Economic Relations, Faculty of \\ Economics and Business Administration, West University of Timișoara, Timișoara, \\ România \\ iulia.elenes74@e-uvt.ro \\ iuliaplatona@gmail.com
}

\begin{abstract}
The german continental model of corporate governance is long term oriented satisfying the different interest of stakeholders-the state, the employees, the society in general and the anglo-saxon model is short term oriented to the purpose of creating value for the shareholders of the company. The research and development objective are corelated with the objective of german model of stakeholder value or of the objective of the anglo-saxon model of shareholder value. We use Eurostat data for European countries for regression analysis to find the relation between gross domestic product as measure of economic growth with the general expenditure for research and development for businness, goverment and academia. We analyse if fixed effects or random effects are more appropriate for our model. The regression analysis shows that the fixed effects model fitts better to our research model.
\end{abstract}

Keywords: corporate governance; research; economic growth

JEL Classification: F43

\section{Literature review}

Starting from the seminal thesis of Berle and Means (1932) that the only purpose of the company is to create value for its shareholders until now, there is no unitary conception regarding the definition of the term "corporate governance". The range of the term is very wide, starting from the supervision of companies and their control based on the mechanism according to which the "stakeholders" exercise control over the "insiders" (Picot 1995) and the management of the company so that their interests are protected,(John, Sembet 1998) until the analysis the interdependencies between the way this enterprise is run and the control exercised over the management and the connection of these interdependencies with the success of the enterprise from the point of view of investors. (Martens 2000).

The concept of corporate governance does not have a unitary definition because it covers a wide range of distinct economic phenomena. The term "corporate governance" has its roots in the Greek "kybernetes" and starts from the Latin "gubernator" and "Corporation" derives from the Latin "corpus". (Allain, 2002).

Feleaga (2006) makes an interesting presentation of the meaning of the term "corporate governance", which in the French academic environment, has been translated most often by corporate governance (government $d$ 'entreprise) and the 
author points out that the English word "governance" is different from the word "government", and for fundamental reasons: governance refers to a device that involves at the same time institutions, relationships, rules and behaviors, is more than the structure represented by the word government .

The translation of the term "corporate governance" must be made considering the anglo-saxon context, which refers to large listed companies, public corporations, which appeal to public savings. The central theme of corporate governance is for Hans Caspar von der Crone (2001) the regulation of the relationship between shareholders as owners on the one hand and the management of the enterprise on the other hand, which is governed by the main agent relationship.

"Corporate governance" refers to the effectiveness of the mechanisms that minimize the conflicts illustrated by the agent theory resulting from the managerial act in general, and in particular refers to legal procedures that prevent managers from expropriating minority shareholders from assets. Warncke (2005) consider that in a broader sense "corporate governance" defines the institutional and legal framework as the internal instruments of the enterprise that have an influence on the management and control of the enterprise as well as on its success. The basic pillars of corporate governance are transparency and accountability to shareholders and other interest groups affected by the company's decisions, in a word "stakeholder".

The shareholder structure and the cultural specificity led to the creation of corporate governance systems adapted to the models of the national specificity continental and Anglo-Saxon models respectively, the "outsider" type systems being specific to the Main Agent problem between owners / shareholders and managers. "Insider" or continental issue Main Agent between the dominant shareholder and the small shareholders. (Roe, (2000), Berndt (2000), Waldenberger (1999), Hobs (2001)). The Anglo-Saxon countries are characterized by highly dispersed driven structures and are characterized as "outsider" systems. In these systems the main agent problem focuses on harmonizing the interests of managers with those of small shareholders. For continental Europe, "insider" systems are specific, focusing on the main agent issue of the significant shareholder, which has a significant package of shares. (Roe (2000), Berndt (2002)). There has long been a heated debate in the economic literature on the issue of orientation towards Shareholder or Stakeholder Value. Bahnmüller and Fisecker (2003) use the WISO database to describe the most important aspects of this debate. The concept of management based on shareholder value principles requires a greater impetus to increase profitability, which results in shortening the horizon of plans made, orientation towards fast and short-term income ("Short Termism"). Managers are oriented towards satisfying the shareholders' desire for quick income

Ther german continental model of corporate governance is long term oriented satisfying the different interest of stakeholders-the state, the employees, the society in general and the anglo-saxon model is short term oriented to the purpose of creating value for the shareholders of the company. The research and development objective are corelated with the objective of german model of 
stakeholder value or of the objective of the anglo-saxon model of shareholder value.

\section{Research metholdology}

For the empirics of economic growth related to research and development we inspire ourselves from the article of (Romer, Mankiw, Weil 1992) employing a Cobb Douglas function in logarithm form for the reason to transform the relation to a linear form.

$$
\log _{e} Y=\alpha_{0}+\sum \alpha_{i} \log _{e} I_{i}
$$

Where, $Y$ is the output, I - the input vector and $\alpha_{i}-$ the estimated coefficients; $\mathrm{Y}=\mathrm{C}^{\alpha} \mathrm{M}^{1-\alpha}, \mathrm{C}$ is the capital and $\mathrm{M}-$ the labor

We use Eurostat data for European countries for regression analysis to find the relation between gross domestic product as measure of economic growth with the general expenditure for research and development for businness, goverment and academia. The dependent variable is the gross domestic product and the independent variables are general expenditures for research and development in the business sector, in the public sector and in the higher education sector.

\section{Regression output and conclusions}

We estimated the following models, using fixed effects and random effects.

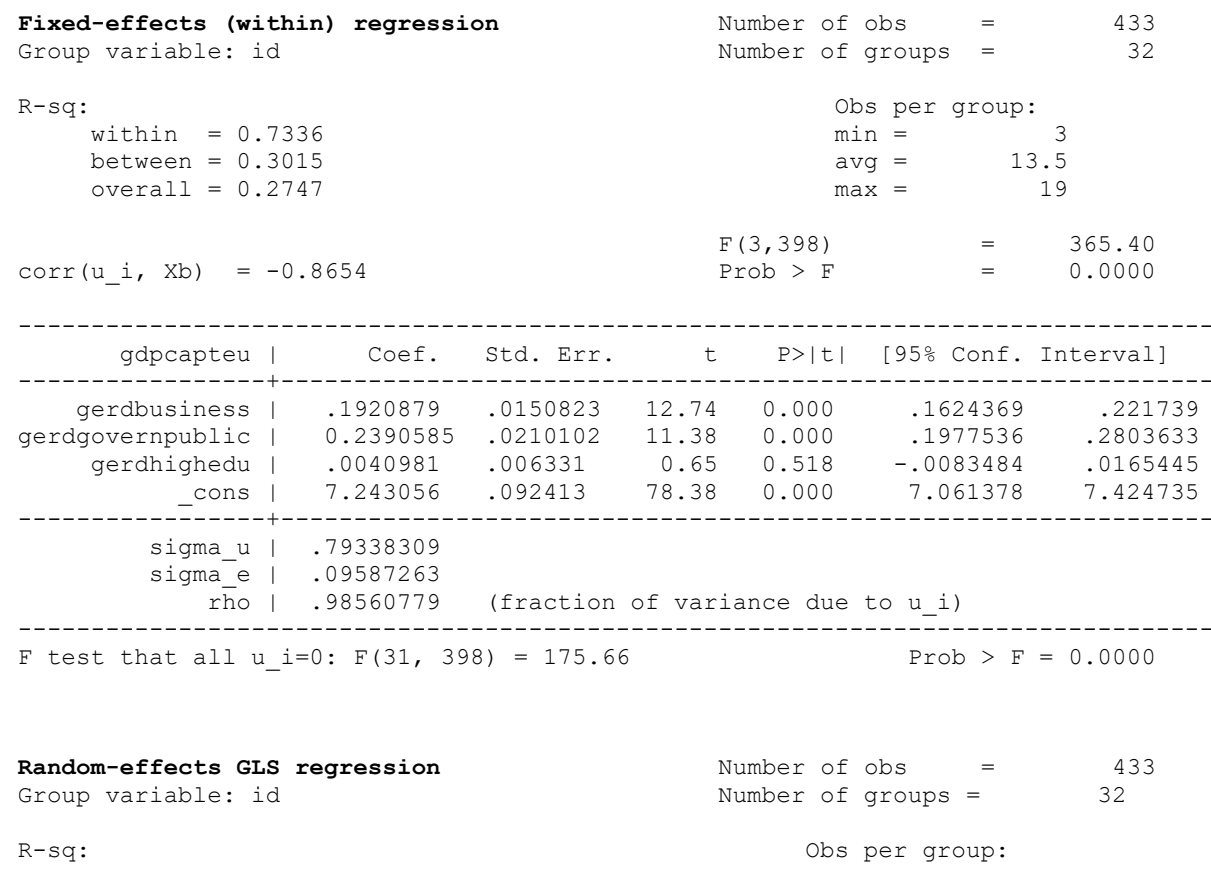




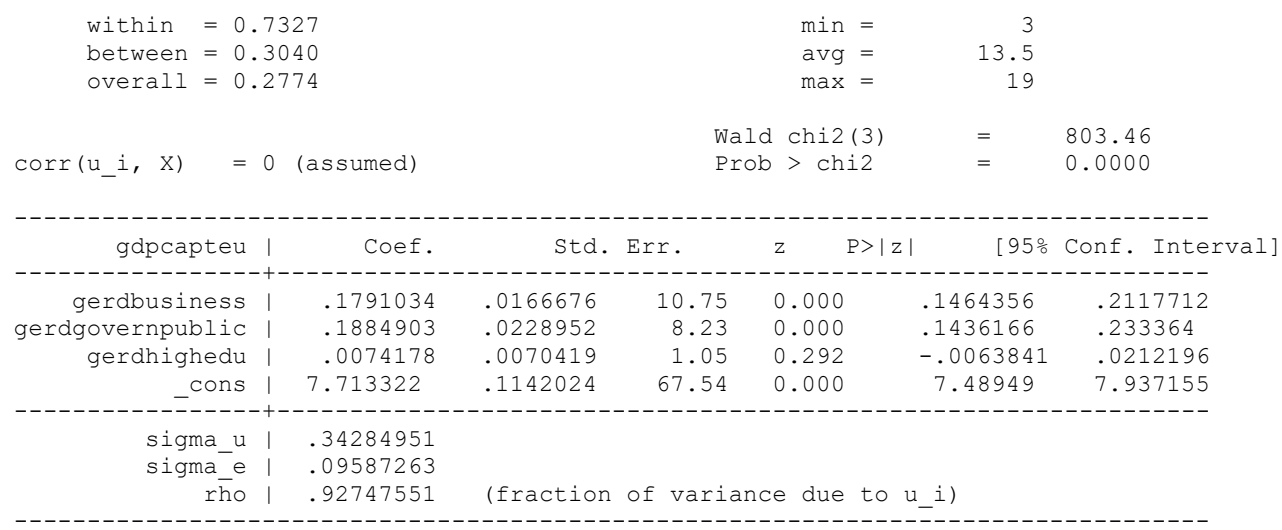

In order to select the adequate model, we performed the Hausman test, based on which we chose the model with fixed effects (Prob>chi2 $=0.0000)$

. hausman m1re mlfe

\begin{tabular}{|c|c|c|c|c|}
\hline & $\begin{array}{l}\text { (b) } \\
\text { m1re }\end{array}$ & $\begin{array}{l}\text { (B) } \\
\mathrm{m} 1 \mathrm{fe}\end{array}$ & $\begin{array}{c}(\mathrm{b}-\mathrm{B}) \\
\text { Difference }\end{array}$ & $\begin{array}{c}\operatorname{sqrt}\left(\operatorname{diag}\left(V_{-} b-V_{-} B\right)\right) \\
\text { S.E. }\end{array}$ \\
\hline $\begin{array}{l}\text { gerdbusiness } \\
\text { gerdgovern C } \\
\text { gerdhighedu }\end{array}$ & $\begin{array}{l}.1791034 \\
.1884903 \\
.0074178\end{array}$ & $\begin{array}{l}.1920879 \\
.2390585 \\
.0040981\end{array}$ & $\begin{array}{r}-.0129845 \\
-.0505682 \\
.0033197\end{array}$ & $\begin{array}{l}.0070944 \\
.0090973 \\
.0030833\end{array}$ \\
\hline
\end{tabular}

$\mathrm{b}=$ consistent under $\mathrm{Ho}$ and $\mathrm{Ha}$; obtained from xtreg

$\mathrm{B}=$ inconsistent under $\mathrm{Ha}$, efficient under Ho; obtained from xtreg

Test: Ho: difference in coefficients not systematic

\begin{tabular}{|c|c|}
\hline chi2 (3) & $\begin{array}{ll}= & (\mathrm{b}-\mathrm{B}))^{\prime}\left[\left(\mathrm{V}_{-} \mathrm{b}-\mathrm{V}_{-} \mathrm{B}\right)^{\wedge}(-1)\right](\mathrm{b}-\mathrm{B}) \\
= & 689.04\end{array}$ \\
\hline $\operatorname{Prc}$ & 0.0000 \\
\hline
\end{tabular}

$\mathrm{R}^{2}$ also tells us the percentage of variation in $\mathrm{Y}$. in our case the GDP that is accounted for by its regression on $X$ in our case GERD business, GERD higher education, GERD Government.

In general an $\mathrm{R}^{2}$ that is close to 1 tells us that the predicted values and the actual values are close together, in contrast a low value of $\mathrm{R}^{2}$ tells us that the regression line does not fit the data well and we can clearly see a larhe amount of distance between the actual values and the predicted values. If $R^{2}$ is 1 the predicted vales fit perfectly the actual values.

The between $\mathrm{R}^{2}$ reports in what measure the variance between separate panel units my model explains for

The within $\mathrm{R}^{2}$ reports in what measure the variance within the panel units my model explains for

The overall $R^{2}$ explains the weighted average of between $R^{2}$ and overall $R^{2}$.

Performing the Hausman test we observe the probability for fixed effects is below 0.05 this means that we use fixed effects. We introduce fixed effects model because we want to control for the individual specific effects and the time specific effects of each country, because when an omitted variable is corelated with the included variables it causes bias. 


\section{References:}

1.Alain, R. (2002): Corporate Governance und Management Entlöhnung, Wirtschaftswissenschaftliches Zentrum (WWZ), Universität Basel, Abteilung Organisation, Führung und Personal, Lizentiatarbeit, eingereicht bei: Prof. Dr. Werner Müller

2. Bahnmüller, R., Fisecker, C. (2003): Dezentralisierung, Vermarktlichung und Shareholderorientierung im Personalwesen. Folgen für die Stellung und das Selbstverständnis des Personalwesens und die Interaktionsmuster mit dem Betriebsrat, FATK Forschungsinstitut für Arbeit, Technik und Kultur, an der Universität Tübingen.

3. Berndt, M, (2000): Global Differences în Corporate Governance Systems. Theory and Implicaţions for Reforms, Harvard John M. Ohlin Center for Law; Economics and Business Discussion Paper $\mathrm{Nr}$ 303,

4. Feleagă, N., Vasile, C. (2006): Guvernanţa întreprinderii între clasicism şi modernism, [Online], Available http://store.ectap.ro/articole/121.pdf

5. Hobs R. (2001): Shareholding and Corporate Governance: Theory and Evidence on Economic Performance, ESRC Centre for Business Research, University of Cambridge

6. John K., Senbet, L.W. (1998) Corporate governance and board efectiveness Journal of Banking \& Finance 22 p. $371 \pm 403$

7. Knuth, M. (1999): Managementüberwachung durch den Aufsichtsrat, Ein Beitrag zur Corporate Governance Diskussion aus agencytheoretischer Sicht, S. 1

8.Mankinw, G, Romer D, and Weil D. (1992) A contribution to the empirics of economic growth. Berkely Edu Papers

9. Roe, M, J, (2000a): Political Foundations for Separating Ownership from Corporate Control, Columbia Law and Economics Working Paper No 155

10. Roe, M. (2000b): Political Precondiţions to Separating Ownership From Corporate Control, Columbia Law Schoo The Center for Law and Economic Working Paper, No 155, Online available: http://papers.ssrn.com/paper.taf?abstract_id=165143, Stand 11.06.2005

11. Waldenberger F., (1999): Die Marktkontrolle im deutschen und japanischen Modell der Unternehmenserfassung, Japan Zentrum, Ludwig MaximiliansUniversität München, Working Paper

12. Warncke, M. (2005): Prüfungsausschuss und Corporate Governance Einrichtung, Organization und Überwachungsaufgabe, Erich Schmidt Verlag, 13. Von der Crone, H., G. (2001): Corporate Governance und Reputation Vom Nutzen eines guten Rufes für Manager und Unternehmen, Fokus der Wirtschaft, Neue Bürcher Zeitung Nr. 22 